U. Herzfeld. Support for field work in the area of the Bering Glacier terminus was provided by the U.S. Geological Survey. We thank G. Streveler, G. Wiles, K. Hale and P. Green for collaboration and assistance with the field program, W. Harrison for useful discussions and S. Ranney for air support.

Geophysical Institute,

University of Alaska,

CRAig S. Lingle

Fairbanks, Alaska 99775-0800, U.S.A.

U.S. Geological Survey (Ret.), 10275 SW 127th Street,

Vashon, Washington 98070, U.S.A.

Scripps Institution of Oceanography,

University of California San Diego,

La Folla, California 92093-0205, U.S.A.

U.S. Geological Survey,

BRUGE F. MOLNIA

National Center, Mail Stop 917,

Reston, Virginia 22092, U.S.A.

U.S. Geological Survey,

Ice and Climate Project,

University of Puget Sound,

Tacoma, Washington 98416, U.S.A.

Geophysical Institute and

Dept. of Geology and Geophysics,

University of Alaska,

Fairbanks, Alaska 99775-0800, U.S.A.

\section{August 1993}

\section{REFERENCES}

Bush, S. 1991. Bering Glacier may be in retreat. Eos, 72(43), 466-467.

Clarke, G.K.C. 1987. Fast glacier flow: ice streams, surging, and tidewater glaciers. J. Geophys. Res., 92(B9), 8835-8841.

Hughes, T. 1992. Theoretical calving rates from glaciers along ice walls grounded in water of variable depths. J. Glaciol., 38(129), 282-294.

Kamb, B. and 7 others. 1985. Glacier surge mechanism: 1982-1983 surge of Variegated Glacier, Alaska. Science, 227(4686), 469-479.

Meier, M. F. and A. Post. 1987. Fast tidewater glaciers. J. Geophys. Res., 92(B9), 9051-9058.

Meier, M. F., L. A. Rasmussen and D. S. Miller. 1985. Columbia Glacier in 1984: disintegration under way. U.S. Geol. Surv. Open-File Rep. 8581.

Molnia, B. 1993. Major surge of the Bering Glacier. Eos, 74(29), 321322.

Pierce, R. A. and J.H. Winslow, eds. 1979. H.M.S. Sulphur on the northwest and California coasts, 1837 and 1839; the accounts of Captain Edward Belcher and Midshipman Francis Guillemard Simpkinson. Kingston, Ontario, The Limestone Press.

Post, A. 1969. Distribution of surging glaciers in western North America. 7. Glaciol., 8(53), 229-240.

Post, A. 1972. Periodic surge origin of folded medial moraines on Bering piedmont glacier, Alaska. F. Glaciol., 11(62), 219-226.

* Present address: Institute of Arctic and Alpine Research, University of Colorado, Boulder, Colorado 80309-0450, U.S.A.
Raymond, C. F. 1987. How do glaciers surge? A review. J. Geophys. Res., 92(B9), 9121-9134.

Reeh, N. 1968. On the calving of ice from floating glaciers and ice shelves. 7. Glaciol., 7(50), 215-232.

The accuracy of references in the text and in this list is the responsibility of the authors, to whom queries should be addressed. 